\title{
108 エタノール燃料対応型内燃機関を適用した教育プログラム
}

\section{Education Program with the Internal-Combustion Engine Using Ethanol Fuel}

\author{
○正内海 能重（埼玉大）中村格芳（広国学院大）渡邊真彦（広国学院大） \\ Noah UTSUMI: Saitama University, 255 Shimo-okubo Sakura-ku, Saitama, \\ Masayoshi NAKAMURA - Mahiko WATANABE: Hiroshima Kokusai Gakuin University, \\ 6-20-1 Nakano, Aki-ku, Hiroshima
}

\begin{abstract}
We applied a commercial motorcycle and remodeled it into the motorcycle which could run using ethanol fuel of E100. In this report, this remodeling method is described, and the influence of the engine ignition using the density of the ethanol is examined. Furthermore, various densities of the engine exhaust emission with the ethanol of E100 and the gasoline of E0 are investigated. Based on these results, we developed the technical education program for the students.
\end{abstract}

Key Words: E100, Technology Utilizing, Education Program, Teaching Materials

\section{1. 緒言}

自動車に適用されるバイオ燃料㐨いて，近年，E3 燃料 (3\%バイオエタノール，97\%ガソリン）の混合然料の使 用が認められた。本ではガソリンに ETBE（Ethyl Tertiary-Butyl Ether) を添加した然料が普及し, 一部の ガソリンスタンドで販売されている。一方，バイオディー ゼル然料については B20 然料( $20 \%$ バイオディーゼル然料， $80 \%$ 軽油)を使用した集塺車や市営バスに利用している地 域もある.したがって，バイオディ一ゼル然料の製造・利 活用や国内産バイオマス原料によるバイオエタノールの製 造法に関する研究は多くなされている1),2).しかしながら， E100（100\%バイオエ夕ノール）などの高濃度エ夕ノール の利活用に関する報告は少なく，特に教育機関で教育に適 用している報告例は見当たらない.

そこで本報ではエタノールを適用した乗り物，すなわち， 市販されている原動機付さ自転車を適用し，E100で可動 する二酸化炭素排出ゼロを目的とした“E100バイク”の 開発を試みた。次に，アルコール濃度によるバイクの実走 実験や E100の燃焼排気ガスを調查し，ガソリン燃料の場 合と比較検討した。ささに，市販されているバイクだけで なく，廉価な汎用エンジンも適用して，実際にエタノール 然料を利活用した教育プログラムの開発を行ったのでここ に報告する。

\section{2. 実験}

2. 1 然料

然料は市販されているレギュラーガソリン，甘糟化学製 試薬一級 $99.5 \%$ エタノル，飲料用のウオッカ“スピリタ ス”アルコール度数 $96 \%$ のお酒，試薬エタノ一ルを蒸留水 で薄めたエタノール濃度 80〜99.5\%のエタノールを適用 した。ガソリンとエタノールの性質の相違は，発熱量はガ ソリンが大きく，エタノール場合およそ 1.7 倍燃費が悪く なる、また，エタノールの場合は引火点が高く，気温が低 い冬にエンジンがかかりにくくなることがわかっている。

\section{2 内燃機関}

本研究で適用した内燃機関は 4 ストロークサイクルエン ジンのみに限定した。 4 サイクルのエンジンオイルはエン ジン下部のオイルパンに溜まっており燃料噴射部分を分離 しているため, エンジンオイルの劣化が抑えられる.また， キャブレター方式による燃料噴射する単気筒の内燃機関を 採用した。インジェクション方式ではコンピュータ制御に
より, 空気と燃料の比を調整するが, 気化器の構造を理解 させる教材には，メカニカルなものが最適であると考えた ため，単気筒のキャブレタ一方式の内燃機関を選択した. 燃料を噴射方るジェットにはアイドリング低回転時はスタ 一タジット・パイロットジェット，中高速回転時のメイン ジェットがある。これらのジェットロの面積によって, 燃 料と空気の比, 空燃比が調整されている。ガソリン然料で は空然比がおよそ 15 となっている。しかしながら，E100 燃料となればガソリン然料用ジェットではエンジンが点火 しない，E100の空然比はおよそ9であるので，ジェット 口の面積を大きくしなければならない。ここでは $15 / 9$ 倍 を目安に桩大させた. ガソリン用の然料ホースは一般的に ゴム製のチューブが適用されているが，本実験ではエ夕， ールに強いシリコンチューブを適用した。然料タンクもシ リコン製の容器に変更し, 燃料フィルター, 然料コック（シ リコン製）を新しく取り付けた。

図 1 は本実験で適用した SUZUKI 製のチョイノリ $50 \mathrm{cc}$ 原動機付き自転車である。また，汎用エンジンはSUBARU 製のロビンエンジン EY-08(78cc)，EY-15(143cc)， $\mathrm{EY}-20(183 \mathrm{cc})$ を適用した. 汎用エンジンはジェット口径の 修正のみでエンジン点火できる。バイクはェアースクリュ 一やアイドリング回転調整用スクリューなどの調整が必要 である。チョークも適宜調整が必要である。これらの調整 は気候やジェット口径にも影響し，経験を必要とする、本 実験で適用した汎用エンジンでは，パイロット・メインジ エットの 2 つなっており,ジェットロの搪大調整が比較 的簡単である。授業時間にゆとりのない場合は，汎用の工 ンジンを用いた方が無難である。

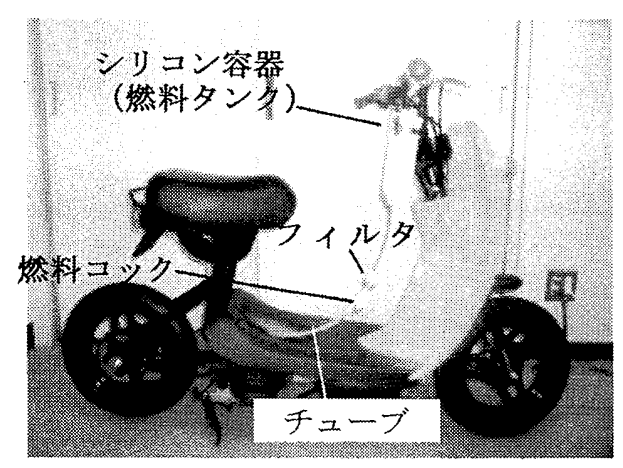

図 1 SUZUKI チョイノリ $50 \mathrm{cc}$

No. 09-90 技術と社会の関連を巡って：過去から未来を訪ねる〔2009-12.12，金沢〕 


\section{3 排気ガス测定}

大気污染に䋆る環境基準として，環境省では $\mathrm{SO}_{2}, \mathrm{CO}$, $\mathrm{SPM}$ (浮遊粒子状物質)，NO$， \mathrm{O}_{\mathrm{x}}$ について基準を設けて いる. 一方, 自動車の排気ガスでは $\mathrm{CO}, \mathrm{HC}, \mathrm{NO}_{\mathrm{x}}, \mathrm{SPM}$ を規制している。ここでは， $\mathrm{SO}_{2}, \mathrm{CO}, \mathrm{HC}, \mathrm{NO}_{\mathrm{x}}$ を測定 対象として取り上げ，測定器はガス検知器・検知管（ガス テック社製）を適用した。

\section{3、結果および考察}

実際の燃料タンクには雨水などの水分が入り込むことが 予測できる。そこで，エタノ一ル濃度の違いによる SUZUKI 製のチョイノリ 50cc のエンジンの実走実験を行 った。エタノール濃度 $95 \%$ までは問題なく走行可能であっ た. $93 \%$ 以下になると, エンジンがかかり難くなり, 走行 ができなくなった。これらの作業はエタノール濃度の選 択・調製とエンジンの始動確証で，比較的簡単な作業でか つ安全であり，指導する側にとっては，作業時間の予測や 調整が可能であるので，本実験は教育用のプログラムとし て妥当であると考える.

各種排気ガスの測定は，測定位置を一定にし，バイクの エンジンの回転数は $2400 \sim 2500 \mathrm{rpm}$ で行った。 図 2 はガ ソリン然料と高濃度エ夕ノ一ル燃料の排気ガスを比較した ものの一例である，窒素酸化物については，エタノ一ル然 料の方が少なく，一酸化炭素や二酸化硫黄については，ガ ソリン然料の方が少なくなった。また，八イドロカーボン は，エタノールが減少し，スピリタスは高くなった。これ らより，エタノール燃料による排気ガスでは堂素酸化物は 減少することがわかったが，他の排気ガスについては，ジ エットやスクリュー調整の具合によって不完全然焼が起こ りやすく，排気がス濃度が高くなったものと判断できる. 硫黄については，燃料の製造過程で硫酸が使われ微量に残 存していること，あるいは，土裹に硫黄功含まれ，バイオ 然料となる原料そのものに含有されている可能性もある。

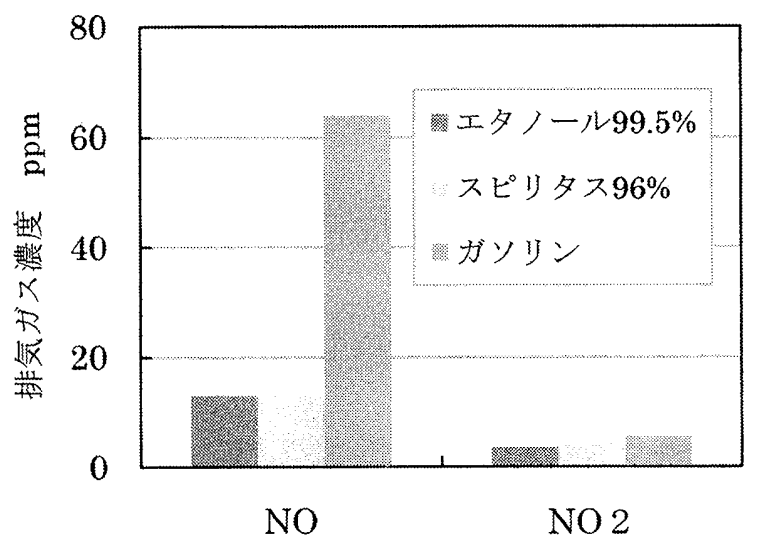

図 2 排気ガス濃度（窒素酸化物の場合）

\section{4. 教育プログラムの開発}

広島国際学院大学工学部において, エタノール詨応型内 燃機関を適用した授業科目を表 2 に，授業内容を表 3 にま とめる。各科目のこれまでの受講者は毎年 5〜12名程度で あった。学生らがエ夕ノ一ル対応型エンジンに変更してい る実習の様子やガス検知管を用いて排気ガス測定している 様子を図 3 に示す，機械系以外の学生も対象とする“技術

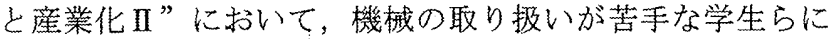
注，汎用エンジンを適用することもある。

近年で仙工具を扱ったことがない学生も見られ，工具の
使い方などの説明も必要なる場合がある。また，エタノ一 ル濃度の影響によるエンジンのかかり具合の調查やガソリ ンとエタノールの燃費の違いなども実験することができる。 さらに，ゴム製のチューブを使ってエタノールによる浸漬 実験も半期の期間で調查ができる.安全への注意も重要で, 排気ガス中毒や火災が発生することも予測されるので，換 気や消火器の常設について十分説明すればよい，最後に実 験のまとめやプレゼンテーションなど追加し，半期 15 回 の講義に十分詨応することができる。

表 1 開講科目

\begin{tabular}{|c|c|c|c|c|}
\hline $\begin{array}{l}\text { 履修 } \\
\text { 年次 }\end{array}$ & 科目名 & 開講年度 & 単位数 & 対象 \\
\hline 1 & $\begin{array}{c}\text { 機械工学基礎 } \\
\text { ゼミナ一ル }\end{array}$ & $\mathrm{H} 18 \sim 20$ & 2(半期必修) & 機械 \\
\hline 2 & 技術と産業化 II & $\mathrm{H} 19$ & 2(半期選択) & 工学部 \\
\hline 3 & $\begin{array}{l}\text { 機械工学 } \\
\text { ゼミナール }\end{array}$ & $\mathrm{H} 18 \sim 20$ & 2 (半期必修) & 機械 \\
\hline 4 & 卒業論文 & $\mathrm{H} 17 \sim 20$ & 4 (通年必修) & 機械 \\
\hline
\end{tabular}

表 2 授羓内容

\begin{tabular}{|c|c|c|}
\hline & まな授菜内容 & 方式・教材等 \\
\hline 1回旦 & 蜸境問題，温室效果ガス，日本の現状 & 誨義・パワーポイント・小テスト \\
\hline 2国目 & バイオ燃料，界と日本の状沉 & 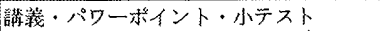 \\
\hline 3㭵白 & ガソリンエンジンの始動と排受ガス㵋定 & 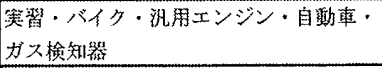 \\
\hline 4国早 & エンジンの分解・組立 & 実䀠・汎用エンジン・I具 \\
\hline 5回鼠 & 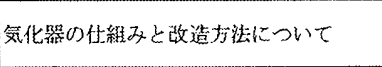 & 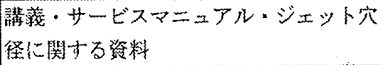 \\
\hline 6回目 & 気化器・㜣料系の改造 & 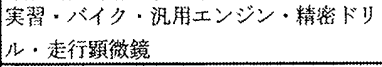 \\
\hline 7回目 & エタノール㜣料による排网ガス测定 & $\begin{array}{l}\text { 実習・バイク・沉用エンジン・ガス検知 } \\
\text { 器 }\end{array}$ \\
\hline 宿題 & レボート作成 & 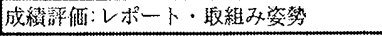 \\
\hline
\end{tabular}

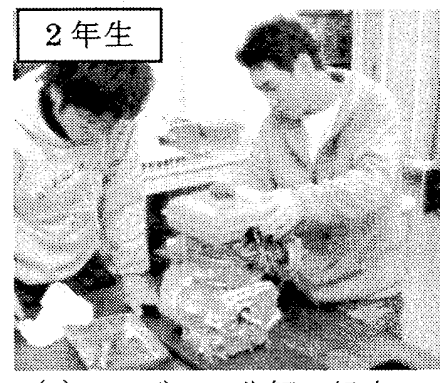

(a)エンジンの分解・組立

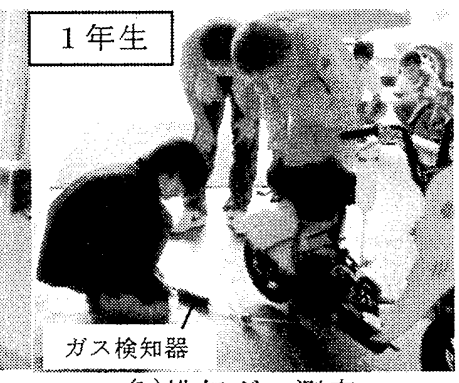

(b)排気ガス測定
図 3 実習の様子

5.まとめ

本研究により，E100 が利活用できる内燃機関の教材を 開発することができた，また，機械工学の導入教育や環境 問題への関心を高める技術教育プログラムを開発すること ができた。

エタノール対応型自動二輪車の開発や実験は，当時，広 島国際学院大学の竹重宽之・嶺尾篤史の学生諸君㧍よびエ ナジーファーム (株) 稲田雄二氏の協力によって行われた ことを記し謝意を表します。

\section{参考 文 献}

1）Bio Fuels World 協議委員会 : Bio Fuels World ビジネ ステクニカルセミナ一予稿集，(2007).

2）国信・内海・土生・中村：第 20 回廃棄物資源循環学 会研究発表会講演論文集，(2009)，281-282. 